Vol. 2, No. 04; 2019

ISSN: 2581-4664

\title{
EFFECT OF BRAND IMAGE AND ADVERTISEMENTS ON CONSUMER DECISIONS TO WATCH MARVEL STUDIOS FILMS AND DC FILMS IN PALEMBANG CITY
}

\author{
M. Liandra Oktavianzah ,Zakariah Wahab and Ahmad Widad \\ Magister Management Sriwijaya University Indonesia \\ http://doi.org/10.35409/IJBMER.2019.2409
}

\begin{abstract}
This research examined the variables of social brand image and advertising on customer decisions. The data used in this study was primary data obtained through a survey of 100 respondents selected randomly in palembangindah mall XXI Theater and using non probability sampling techniques. The study used multiple linear regression analysis which found that brand image variables had a positive but not significant effect while variables advertising had a more positive and significant effect on customer decision watching's Marvel Studios and DC Films in Palembang city.
\end{abstract}

Keyword: brand image, advertising and consumer decision.

\section{INTRODUCTION}

Kotler and Armstrong (2013) "Brand image is a set of beliefs held about a particular brand is known as brand image". Is a set of beliefs about a brand called brand image. According to Keegan and Green (2012) "advertising is messages that are elements of art, text / writing, titles, photographs, tageline, other elements that have been developed for their suitability". According to Kotler (2012), "purchasing decisions are actions of consumers to want to buy or not to the product". From various factors that can influence consumers to decide to buy a product or service, consumers will consider the price, product, and quality factors that are known to the public before deciding to make a purchase, consumers will go through several phases first, namely problem recognition, information seeking, evaluation alternatives, buying or not decisions, and finally post-purchase behavior.

According to law number 8 of 1992 "Film is a work of art and culture that is a listening-view mass communication media made based on the principle of cinematography by recording it on celluloid ribbons, video tapes, video discs, or other technological inventions in all shape, type, and size through chemical processes, electronic processes, or other processes with or without sound that can be displayed with mechanical, electronic or other projection systems ". Marvel's success in producing Superhero films became a new culture since the Iron Man (2008) film was a success in the market, making world film industry giant Walt Disney buy Marvel ownership in 2009, making Marvel easier in promoting comic characters they have such as Iron Man, Captain America, Thor, Hulk, Spider-man and various kinds of new Superhero characters that are not yet widely known such as Guardian of the Galaxy, Ant-man, Black Panther and Superheroes like 


\section{International Journal of Business Management and Economic Review}

Vol. 2, No. 04; 2019

ISSN: 2581-4664

Captain Marvel were released in 2019.

The success of Marvel Studios in the last 10 years has of course caused the competitor who was already present, DC Comics, to try to follow in the footsteps of Marvel Studios by using the Shared Universe concept where the films produced have a continuity of stories and interrelationships between the films. DC Films began its film project with the release of Man of Steel (2013), Batman vs Superman: Dawn of Justice (2016), Suicide Squad (2016), Wonder Woman (2017), Justice League (2017), and Aquaman (2018).

After a brief observation of how far the knowledge of the people who watched Superhero-themed films, I was interested in conducting research on "The Effect of Brand Image and Advertisements on Consumer Decisions to Watch Marvel Studios and DC Films in Palembang City.

\section{LITERATURE REVIEW}

\section{Brand Image}

Kotler and Armstrong (2013) suggested the notion of brand image "The set of belief held about a particular brand is known as brand image". Which means a set of beliefs about a brand is called a brand image.

\section{Advertisement}

according to Keegan and Green (2012) "advertising is messages that are elements of art, text / writing, titles, photographs, tageline, other elements that have been developed for their suitability".

\section{Consumer Decisions}

According to Kotler (2012), "purchasing decisions are actions of consumers to want to buy or not to the product". From various factors that can influence consumers to decide to buy a product or service, consumers will consider the price, product, and quality factors that are already known to the public before making a purchase. Consumers will go through several phases first, namely recognizing problems, seeking information, evaluating choices, purchasing decisions, and evaluating purchases.

\section{Framework Model}

Based on existing theories, the framework of this research can be described as follows: 


\section{International Journal of Business Management and Economic Review}

Vol. 2, No. 04; 2019

ISSN: 2581-4664

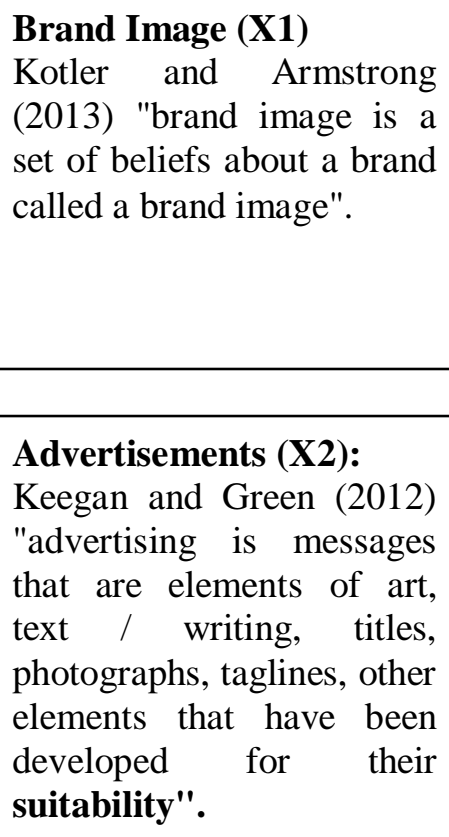

Consumer Decision (Y):

Kotler (2012) 'is the action of consumers

to want to buy or not for a product.

Figure 1. Thinking Framework

\section{Hypothesis}

The hypothesis is a temporary answer that is still guessed and still has to be verified. Then this hypothesis was made intended to provide an analysis direction from a study, the provisional estimates in this study can be explained as follows:

H1. There is the influence of Brand Image and Advertisements on Consumer Decisions to watch Superhero films in Palembang.

H2. There is no effect of Brand Image and Advertisements on Consumer Decisions to watch Superhero films in Palembang.

\section{RESEARCH METHODS}

\section{The scope of research}

The scope of this study discusses the influence of Brand Image and Advertisements on consumer decisions to watch the production of Marvel Studios and DC Films Superhero films in Palembang City. The consumers who want to be studied are the people of Palembang, especially fans of Superhero films.

\section{Research design}

The research design used is a causal study, namely research designed to find a relationship between causal variables. There are two types of variables in this study, namely the independent variable Brand and Ad Image and the dependent variable is consumer decisions. 


\section{International Journal of Business Management and Economic Review}

Vol. 2, No. 04; 2019

ISSN: 2581-4664

\section{Types and Data Sources}

This study uses two main types of data sources, namely:

Primary data, namely data obtained by the author directly using the questionnaire method by using a set of questions or statements to consumers who know the Superhero characters and watch at least 5 Superhero films Marvel Studios or 3 DC films which are then processed into sources of information in this study.

Secondary data, namely data obtained by internet writers and journals as reference material for this research.

\section{Data collection technique}

Data Collection Techniques in this study used a closed questionnaire model where the answers were prepared by the researcher. Respondents were asked to answer one of the answer choices from the questions provided. Reasons for using the questionnaire as a data collection technique because:

a. This research is quantitative research that is using numbers as a measurement benchmark so, the questionnaire method represents the opinions of respondents in the form of a questionnaire.

b. Researchers need diverse opinions from several people as material for consideration analysis.

\section{Population and Samples}

Population According to Nazir (2005) "population is a group of individuals with qualities and characters that have been determined by researchers. The characteristic or quality is called a variable ". The test population this time is citizens of Palembang city aged 16-25 years who are fond of Superhero characters who have watched Superhero films through Cinemas.

Samples according to Sugiyono (2012) "Samples are part of the number of characteristics possessed by the population". Because the number of populations unknown in this study, several samples were taken to represent the population.

\section{Data analysis technique}

\section{Validity test}

Validity Test is a tool used to test how carefully or valid a questionnaire is. The validity test itself is a test used to measure the validity of a questionnaire, because a questionnaire can be declared valid if the statement on the questionnaire is able to express something that will be measured by the questionnaire.

\section{Reliability Test}

Reliability Test is a tool to measure a questionnaire which is an indicator of a variable. A questionnaire can be declared reliable if the answers from respondents are consistent or fixed. In this writing the measurement technique used is using the Cronbach Alpha technique.

\section{Analysis of Multiple Linear Regression}

Analysis of Multiple Linear Regression is used to answer the problem statement in this study, the analysis carried out is multiple regression analysis. This analysis is used to analyze the influence 


\section{International Journal of Business Management and Economic Review}

Vol. 2, No. 04; 2019

ISSN: $2581-4664$

between the independent variables Brand and Advertisements on the dependent variable, namely Consumer Decision watching Marvel Studios and DC Films films in Palembang.

\section{Coefficient of Determination}

The coefficient of determination is a test that is used as a measure of the ability of independent variables to influence the dependent variable. The coefficient of determination measured using $\mathrm{R} 2$, if $\mathrm{R} 2$ has a value close to 1 , the greater an independent variable can explain its effect on the dependent variable.

The following is a model that can be described from the coefficient of determination

Where :

$$
Y=a+b_{1} C M+b_{2} I K+e
$$

$\mathrm{Y}=$ Consumer Decision

a $=$ Constant

b1, b2 = regression line coefficient

CM = Brand Image

IK = Advertisements

$\mathrm{E}=$ Standard error

TEST RESULT

Test of Research Instruments

Table 1. Test of Validity of Research Instruments

\begin{tabular}{|ccccc|}
\hline Variable & Questions & r-tabel & r-hitung & Information \\
\hline & Question 1 & 0.2960 & 0.834 & Valid \\
Brand Image & Question 2 & 0.2960 & 0.813 & Valid \\
(X1) & Question 3 & 0.2960 & 0.821 & Valid \\
& Question 4 & 0.2960 & 0.879 & Valid \\
& Question 5 & 0.2960 & 0.885 & Valid \\
\hline \multirow{3}{*}{ Advertisement } & Question 1 & 0.2960 & 0.834 & Valid \\
(X2) & Question 2 & 0.2960 & 0.813 & Valid \\
& Question 3 & 0.2960 & 0.821 & Valid \\
& Question 4 & 0.2960 & 0.879 & Valid \\
\hline \multirow{3}{*}{ Consumer } & Question 1 & 0.2960 & 0.832 & Valid \\
Decision (Y) & Question 2 & 0.2960 & 0.818 & Valid \\
& Question 3 & 0.2960 & 0.743 & Valid \\
& Question 4 & 0.2960 & 0.895 & Valid \\
& Destion & 0.2960 & 0.861 & Valid \\
\hline
\end{tabular}

Source: data source processed 2019 


\section{International Journal of Business Management and Economic Review}

Vol. 2, No. 04; 2019

ISSN: 2581-4664

Based on the validity test table of the research instruments above, it can be seen that all statement items used in this study are valid, which are indicated by the values contained in the calculation of the greater value than the r-table of 0.2690 .

\section{Research Instrument Reliability Test Results}

Reliability Test is used to find out whether a research instrument has obstacles in measuring a dimension. The reliability test results for each variable in the value using the cronbach's alpha method as a measuring instrument and the results can be seen as follows:

Table 2. Test of Reliability of Research Instruments

\begin{tabular}{|clccc|}
\hline No & \multicolumn{1}{c}{ Variabel } & $\begin{array}{c}\text { Alpha } \\
\text { Cronbach }\end{array}$ & Alpha & Information \\
\hline 1 & X1 (Brand Image) & 0,6 & .899 & Reliable \\
2 & X2 (Advertisement) & 0,6 & .864 & Reliable \\
3 & Y (Consumer Decision) & 0,6 & .887 & Reliable \\
\hline
\end{tabular}

Based on the data above, it can be seen that all research instruments used are reliable because the test values shown in the Alpha column all show values above 0.6 if compared to the Cronbach alpha scale column.

\section{Simultaneous Test (F Test)}

Is a test to determine the effect of independent variables namely brand image (X1) and advertising (X2), simultaneously or simultaneously on the dependent variable, namely consumer decisions (Y). The criteria used are as follows:

$>$ There is no significant effect if the probability level is F (Sig F) $>0.05$

$>$ Significant effect if the probability level F (Sig F) $<0.05$

The test results using SPSS series 17 can be seen through the ANOVA table below as follows:

Table 3. ANOVA output

\begin{tabular}{|lccccc|}
\hline & $\begin{array}{c}\text { Sum of } \\
\text { Squares }\end{array}$ & Df & $\begin{array}{c}\text { Mean } \\
\text { Square }\end{array}$ & F & Sig. \\
\hline Regressio & 6.412 & 2 & 3.206 & 174.930 &, $000^{\mathrm{b}}$ \\
$\mathrm{n}$ & & & & & \\
Residual & 1.778 & 97 & .018 & & \\
Total & 8,190 & 99 & & & \\
\hline
\end{tabular}

Source: Primary data processed, 2019

From the F test table above, it can be seen that the ANOVA table has a value of 99 degrees of freedom (df) obtained from the quality of Fcount with a value of 3.143 greater than Ftable (df 2:97) with a confidence level of $97 \%$ with a value of 3.09 (F count 3.143> F table 3.09), and the probability value of significance $F=0,000$ is smaller than the alpha value in table $F$ count of 


\section{International Journal of Business Management and Economic Review}

Vol. 2, No. 04; 2019

ISSN: 2581-4664

0.005. This shows that $\mathrm{H} 1$ is accepted and $\mathrm{H} 2$ is rejected, meaning that the brand image variable (X1) and advertisement (X2) together have a significant influence on consumer decisions to watch films produced by Marvel Studios and DC Films in Palembang.

\section{Partial Test}

\section{Partial Test (T Test)}

The $\mathrm{T}$ test was conducted to test the significance of the constants of each independent variable, namely brand image (X1) and advertisement (X2) which actually had a partial effect on the dependent variable, namely consumer decisions. If $\mathrm{T}$ count is greater than $\mathrm{T}$ table, then $\mathrm{H} 1$ is accepted and $\mathrm{H} 2$ is rejected, whereas if $\mathrm{T}$ count is smaller than T table, $\mathrm{H} 1$ is rejected and $\mathrm{H} 2$ is accepted. For testing purposes, use $\mathrm{T}$ count at a confidence level of $5 \%$ or 0.05 . The results of the $T$ test using SPPS series 17 are as follows:

\section{Table 4. Output Coefficients}

\begin{tabular}{|cccccc|}
\hline \multicolumn{7}{c|}{$\begin{array}{c}\text { Unstandardized } \\
\text { Coefficients }\end{array}$} & $\begin{array}{c}\text { Standardized } \\
\text { Coefficients }\end{array}$ & & \\
& $\mathrm{B}$ & Std. Error & Beta & $\mathbf{t}$ & Sig. \\
\hline (Constant) & .09 &. & & 1.61 & \multirow{2}{*}{110} \\
& 1 & .056 & & 3 & \\
$\mathrm{X} 1$ & .13 & & & 2.33 & .021 \\
& 6 & .058 & .149 & 7 & \\
$\mathrm{X} 2$ & .77 & & & 12.1 & .000 \\
& 8 & .064 & .778 & 88 & .00 \\
\hline
\end{tabular}

Source: Primary data processed, 2019

Based on the analysis of the $\mathrm{T}$ test can be described as follows:

1. The value of $\mathrm{T}$ count $\mathrm{X} 1$ variable is $2,337>1,983$, with a significance value of $0.021>0.05$ which indicates that $\mathrm{H} 1$ is accepted and $\mathrm{H} 2$ is rejected, this means that the brand image variable has a partial influence on consumers' decision to watch Marvel Studio films in Palembang.

2. The calculated $\mathrm{T}$ value of the $\mathrm{X} 2$ variable is $12,188>1,983$, with a significance value of $0.025<0.05$ which indicates that $\mathrm{H} 1$ is accepted and $\mathrm{H} 2$ is rejected, this means that there is a partial significant influence between variables Advertisements on consumer decisions watching Marvel Studios and DC Films produced in Palembang city.

\section{Determination Coefficient Test}

Test of determination coefficient ( $\mathrm{R}$ square) is a test that looks at how much influence the independent variable $(\mathrm{X})$ has on the dependent variable $(\mathrm{Y})$. The table below can explain the coefficient of determination of brand images and advertisements on consumer decisions that are tested using SPSS series 17 are as follows: 


\section{International Journal of Business Management and Economic Review}

Vol. 2, No. 04; 2019

ISSN: 2581-4664

\section{Table 5.coefficient of determination}

\begin{tabular}{|ccccc|}
\hline R & R Square & $\begin{array}{c}\text { Adjusted R } \\
\text { Square }\end{array}$ & $\begin{array}{l}\text { Std. Error of } \\
\text { the Estimate }\end{array}$ & $\begin{array}{c}\text { Durbin- } \\
\text { Watson }\end{array}$ \\
\hline .865 & .783 & .778 & .135 & 2.016 \\
\hline
\end{tabular}

Source: Primary data processed, 2019

Based on the output table above it is known that the value of the coefficient of determination of brand image and advertisement variables is equal to 0.783 or equal to $78.3 \%$. This figure shows the variable brand image (X1) and advertising (X2) simultaneously has an influence on consumer decisions $(\mathrm{Y})$ of $78.3 \%$ while the rest $(100 \%-78.3 \%=21.7 \%)$ is influenced by other variables in outside of this research that influences consumer decisions such as promotional variables that influence consumer decisions.

\section{Analysis of Multiple Linear Regression}

Multiple Linear Regression Analysis is a method that is useful to find out the causal relationship that occurs between the independent variables namely brand image (X1) and advertisement (X2) on the decisions of consumers watching Marvel Studios and DC Films in Palembang. As for results of multiple linear regression analysis tested using SPSS series $17 \mathrm{can}$ be seen as follows:

$$
\mathrm{Y}=\mathrm{a}+\mathrm{b} 1 \mathrm{X} 1+\mathrm{b} 2 \mathrm{X} 2+\mathrm{e}
$$

Where the results can be seen as follows:

$$
\mathrm{Y}=0.091+0.136 \mathrm{X} 1+0.778 \mathrm{X} 2
$$

From the model above shows there is an influence between the variable brand image (X1) with a value of 0.091 and advertising (X2) with a value of 0.778 . There are positive values in the two independent variables (X), so this shows an influence on consumer decisions (Y) to watch Marvel Studios and DC Films films in Palembang city in addition to other factors not included in this study.

\section{DISCUSSION}

Based on research results that have been tested using the SPSS Series 17 can be seen brand image of a company that is good in the eyes of consumers, can influence consumers' decisions to watch Marvel Studios and DC Films films. The results of testing carried out in this study using SPSS series 17 showed that the independent variable of brand image (X1) has a significance value of $0.021<0.05$ so that it has a significant influence on the dependent variable, namely consumer decisions. According to Keller (2013) Brand image is "a perception of a brand that is a reflection of consumer memory of its association with that brand".

Based on the results of research that has been tested using SPSS Series 17 can be seen the advertisement variable (X2) also has a significance value of $0,000<0.05$ so that it has a significant influence on the dependent variable namely consumers' decision to watch films produced by Marvel Studios and DC Films in Palembang. According to Keegan and Green (2012) "advertising is messages that are elements of art, text / writing, titles, photographs, 


\section{International Journal of Business Management and Economic Review}

Vol. 2, No. 04; 2019

ISSN: 2581-4664

taglines, other elements that have been developed for their suitability". So that advertising can be seen as part of media promotion plays an important role and has a significant influence on consumer decisions.

The advertising variable (X2) has the most dominant influence on consumers' decision to watch Marvel Studios and DC Films produced in Palembang. It can be seen from the significance value of 0,000 smaller than the variable significance of brand image of 0.021 so that the advertising variable has a stronger influence partially towards consumer decisions to watch films produced by Marvel Studios and DC Films.

\section{CONCLUSION}

Based on the analysis and discussion in the previous chapter, it can be concluded as follows:

Based on the analysis and discussion in the previous chapter, it can be concluded as follows:

1. Simultaneously the independent variables namely brand image (X1) and advertising (X2) have a simultaneous influence on consumer decisions to watch films produced by Marvel Studios and DC Films in Palembang. This makes the two variables simultaneously very influential on the decisions of consumers watching Marvel Studios and DC Films.

2. Partially brand image variables (X1) and advertisements (X2) have a significant positive influence on consumers' decisions to watch films produced by Marvel Studios an DC Films in Palembang. This makes individual brand image variables and advertisements in the eyes of consumers have a significant influence on consumer decisions.

3. The advertising variable (X2) partially has the most dominant influence on consumer decisions watching films produced by Marvel Studios and DC Films in Palembang

\section{SUGGESTION}

Based on the results of research, discussion and conclusions, the suggestions that can be given are as follows.

\section{Company:}

1. Marvel Studios and DC Films in maintaining their brand image are advised to consistently produce superhero films that are quality and unique both in terms of story, superhero characters and good film quality so consumers can get to know and associate the Marvel Studios and DC Films brands as companies quality comic publications and superhero films.

2. Marvel Studios and DC Films are advised to increase their advertising activities through social media such as Youtube, Twitter and Instagram to encourage wider consumers to introduce films produced by Marvel Studios and DC Films and also to hold watching activities for fans when the film is released by inviting the actor or actress who plays a superhero character or author or writer of Marvel or DC comics so that it will enhance the relationship between fans and superhero characters in the film. 
Vol. 2, No. 04; 2019

ISSN: 2581-4664

\section{REFERENCES}

1. $\quad$ Aaker, D. A. (2000). Managing Brand Equity. New York: Free Press

2. Amstrong, Gary \& Philip, Kotler. 2012. Dasar-dasarPemasaran. Jilid 1, AlihBahasa Alexander Sindorodan Benyamin Molan. Jakarta: PenerbitPrenhalindo

3. Buchari Alma, 2005. ManajemanPemasarandanPemasaranJasa. Cetakan 5. Bandung : CV Alfabeta

4. Charles W. Lamb, Joseph F. Hair, Carl Mcdaniel. 2001. Pemasaran. EdisiPertama, SalembaEmpat, Jakarta.

5. DikaSetiagraha, Dr. ZakariaWahab, MBA, Welly Nailis.2015. AnalisiPengaruh Brand Image dan Brand Awareness terhadap Brand Equity Obat Herbal EkstrakKulitManggisMastin (StudiKasusMayarakat Kota Palembang). JurnalUniversitasSiwijaya.

6. FandyTjiptono (2008). Service Management MewujudkanLayanan Prima penerbit C. V ANDI OFFSET Edisi II Yogyakarta

7. J. Setiadi, Nugroho, SE., MM., 2003, "PerilakuKonsumenKonsepdanImplikasiuntukStrategidanPenelitianPemasaran". Jakarta: Kencana.

8. Keller, Kevin Lane. 2008. Strategic Brand Management: Building, Measuring, and Managing Brand Equity. New Jersey: Prentice Hall Inc.

9. Kotler, Philip and Keller, Kevin Lane. 2012. Marketing Management 13. New Jersey: Pearson Prentice Hall, Inc.'

10. Kumar, Dr. D.Prasanna\& K. Venkateswara Raju.2013.The Role of Advertising in Consumer Decision Making.IOSR Journal of Business and Management (IOSR-JBM.PP 37-45.

11. Muhammad Ehsan Malik, Muhammad MudasarGhafoor, Hafiz KashifIqbal, Qasim Ali, HiraHunbal, Muhammad Noman and Bilal Ahmad.2013. Impact of Brand Image and Advertisement on Consumer Decision. World Applied Sciences Journal 23 (1): 117-122.

12. Onigbinde Isaac Oladepo (Ph.D.) \&Odunlami Samuel Abimbola (M.Sc.).2015.The Influence Of Brand Image and Promotional Mix On Buying Decision- a study of Beverage Consumers In Lagos State, Nigeria.British Journal of Marketing Studies Vol.3, No.4,pp.97-109.

13. Schiffman, L.G, danKanuk, L.L. 2007, Consumer Behavior 9th edition., Pearson PrenticeHall., New Jersey.

14. Simamora, Bilson. 2001. Remarketing for Business Recovery. Jakarta :GramediaPustakaUtama.

15. Solomon, R. Michael dan Stuart, W. Elnora, 2003, Marketing Real People, Real Choices, International Edition, Prentice Hall, New Jersey.

16. Sugiarto, dkk. 2001. Teknik Sampling. Gramedia. Jakarta.

17. Sugiyono. 2012. MetodePenelitianBisnis (PendekatanKuantitatif, Kualitatif, dan R\&D). Alfabeta. Bandung.

18. Suliyanto. 2005. Analisis Data. Ghalia Indonesia. Bogor.

19. Surachman. $2008 . \quad$ Dasar-dasarManajemenMerek (AlatPemasaranuntukMemenangkanPersaingan). Malang: Bayumedia Publishing. 
Vol. 2, No. 04; 2019

ISSN: 2581-4664

20. SwasthadanIrawan. 2008. ManajemenPemasaranModern.Liberty Yogyakarta

21. Syed SaadHussain Shah, Jabran Aziz, AhsanrazaJaffari, Sidra Waris, WasiqEjaz, Maira Fatima and Syed Kamran Sherazi.2012.The Impact of Brands on Consumer Purchase Intentions. Asian Journal of Business Management 4(2): 105-110.

22. Tony Sitinjak\&Tumpal. (2005). Pengaruh Citra Merek Dan SikapMerekTerhadapEkuitasMerek. JurnalManajemenMerek. Vol 12 No.2 Juni 2005.

23. Warren J. Keegan, ManajemenPemasaran Global, Jakarta : PT IndeksGramedia, 2003.

24. XuemeiBian Business School, University of Nottingham, Nottingham, UK, and LuizMoutinho Management Department, University of Glasgow, Glasgow, UK.2009.The role of brand image, product involvement, and knowledge in explaining consumer purchase behaviour of counterfeits Direct and indirect effects.European Journal of Marketing Vol. 45 No. 1/2, 2011 pp. 191-216. 